\title{
ICE STREAMS AND GROUNDING ZONES OF WEST ANTARCTICA AND THE ROSS ICE SHELF
}

(Abstract)

by

\author{
S. Shabtaie and C.R. Bentley
}

(Geophysical and Polar Research Center, University of Wisconsin-Madison, 1215 W. Dayton Street, Madison, WI 53706, U.S.A.)

\section{ABSTRACT}

In 1984-85, airborne radar soundings were carried out over West Antarctic ice streams A, B, and C, the neighboring parts of the Ross Ice Shelf, and Crary Ice Rise. Here we use the radar data to map the boundaries of the ice streams, to calculate surface elevations, and to measure ice thicknesses. Ice thicknesses and surface elevations have been used together to map the grounding zones and ice rises (Figure 1).

Elevations above sea level were determined from

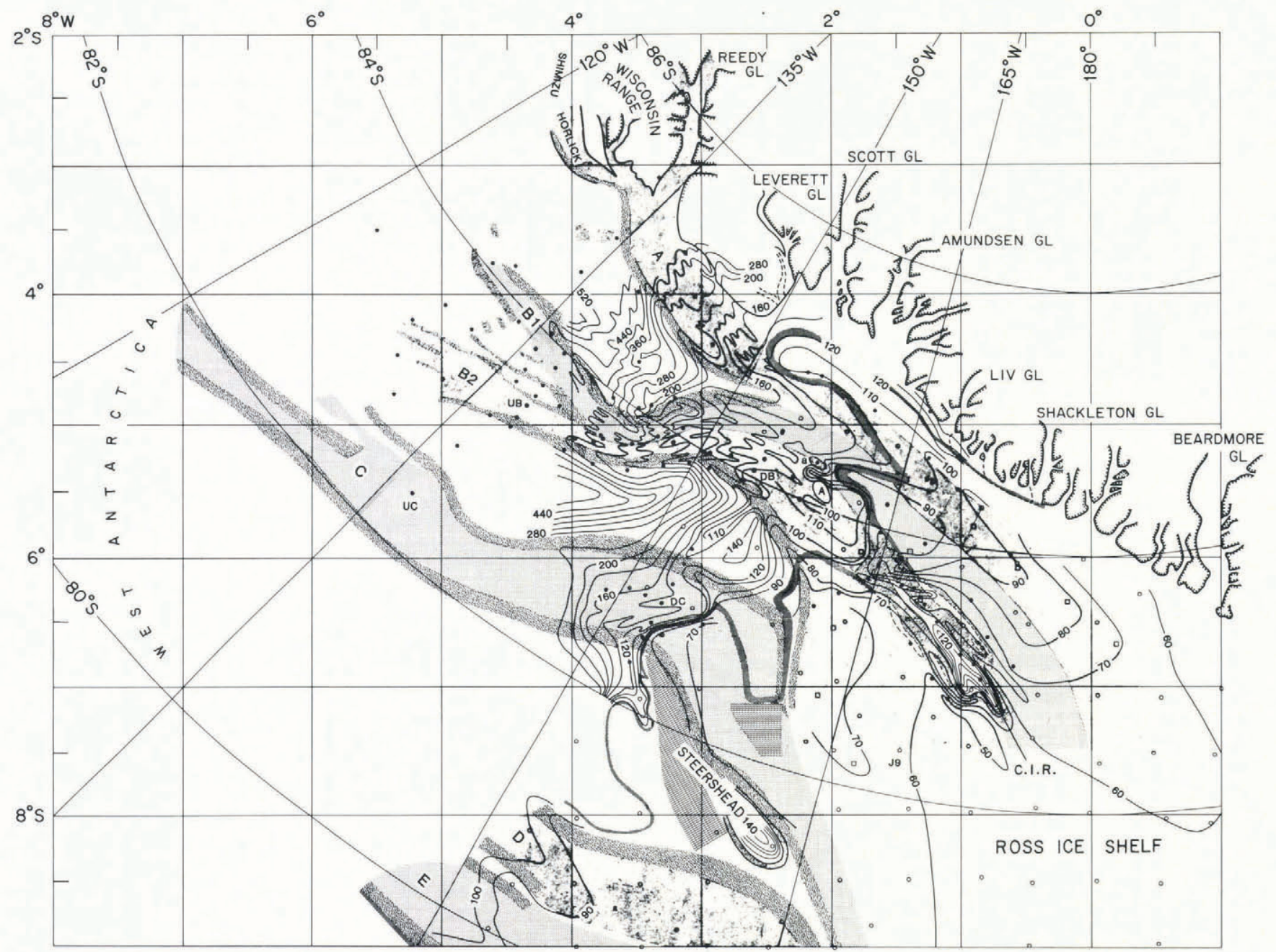

Fig.1. Map of ice streams, ice rises, and grounding zones of West Antarctica and their associated flow bands on the Ross Ice Shelf. The heavy shadings are the marginal shear zones, and light shadings are the relatively less chaotic parts of the ice streams. The base camps (UP, DB, UC, DC) GSIRE stations (dots), RIGGS stations (open circles), and IGY traverse stations (open squares) are shown. The ice rises are shown with solid outlines and no shading (e.g. "a", "A", C.I.R., Steershead). There are four narrow strips (no shading) around C.I.R. (Crary Ice Rise) that we have interpreted also as ice rises. The parallel shading around ice rises denotes heavily crevassed marginal areas. Grounding lines are shown as a band of cross-hatching (the grounding lines for ice streams D and E are not shown). The parallel hatching around and upstream of C.I.R. is a zone of intensive crevassing and is partially grounded in some locations. The areas marked with a wavy pattern are zones of surface and bottom rumples, wherein we believe the ice shelf to be partially grounded. Contours (solid lines) are at $10 \mathrm{~m}$ intervals up to $120 \mathrm{~m}$, at $20 \mathrm{~m}$ intervals from $120-200 \mathrm{~m}$, and at $40 \mathrm{~m}$ intervals at higher elevations. 
Doppler-satellite heights above the reference ellipsoid and the GEM 10C geoidal model. A regression line of height above sea level vs. ice thickness proved useful for distinguishing between floating and grounded ice. Deviations from hydrostatic equilibrium of about $10 \mathrm{~m}$ or more were detectable. Application of this criterion has led to detection of several ice rises and ice rumples (Figure 1).

The surfaces of the active ice streams, A and B, are heavily crevassed and their boundaries are marked by chaotic, incoherent bands of surface crevasses, but there are no visible crevasses on ice stream C. However, sounding on the surface of ice stream $C$, using a carrier-free monopulse radar, has revealed numerous crevasses buried at a depth of about $35 \mathrm{~m}$, which corresponds to about 250 years of snow accumulation. This suggests that ice stream $\mathrm{C}$ ceased to be active about 250 years ago.

Crevasses at or near the surface produce a distinctive back-scattered radar return (clutter) that we have used to map the ice streams and their extensions onto the ice shelf. The lack of "clutter" on slowly-moving ice, along with the surface elevation data, has enabled us to extend the mapped boundary of Crary Ice Rise about $70 \mathrm{~km}$ upstream, and to map several other ice rises (Figure 1).

\section{ICE-SHEET THICKENING OBSERVED BY SATELLITE ALTIMETRY \\ (Abstract)}

by

H.J. Zwally

(NASA, Goddard Space Flight Center, Greenbelt, Maryland 20771, U.S.A.)

\section{ABSTRACT}

The first set of sequential measurements by two different sets of satellite altimetry data indicate that the Greenland ice sheet, south of $65.1^{\circ}$ north latitude, thickened at the rate of $35 \pm 17 \mathrm{~cm} \mathrm{a}^{-1}$ during 1975 to 1978. The average change in surface elevation was calculated from the elevation differences determined at 525 locations observed by both GEOS-3 and Seasat radar altimeters. The observed thickening is consistent with the $8 \mathrm{~cm} \mathrm{a} \mathrm{a}^{-1}$ thickening previously measured in the accumulation zone, approximately
$900 \mathrm{~km}$ farther north, during conventional, surface, survey methods. The increase in ice thickness suggests a higher precipitation than the long-term average, which is one possible result of a warmer climate in polar regions. The excess ice accumulation, in the $10 \%$ of the Greenland ice sheet observed, is estimated to be $53 \mathrm{~km}^{3} \mathrm{a}^{-1}$, which is equivalent to a sea-level reduction of $0.15 \mathrm{~mm} \mathrm{a}^{-1}$. Additional, high-precision, sequential, altimetric measurements could be used to determine the overall mass balance of the Greenland and Antarctic ice sheets. 